\title{
The Influence of Leadership and Satisfaction Work on Nursing Performance Through Motivation as an Intervening at
} a Public Hospital

Besse Pasrah Indah

Student in Magister of Management

University of Merdeka Malang, Indonesia

\author{
Sunardi \\ Associate Professor \\ Faculty of Economics and Business \\ Universitas Merdeka Malang, Indonesia \\ Harianto Respati ${ }^{1}$ \\ Faculty of Economics and Business \\ Universitas Merdeka Malang, Indonesia \\ Email: patidarma@yahoo.com \\ Indonesia
}

\section{ABSTRACT}

This study examines four variables namely leadership style, job satisfaction, motivation, and nurse performance. The purpose of this study is to analyze and explain the effect of leadership and job satisfaction on nurse performance by testing individual motivation as intervening. The research respondents were nurses with government employees who worked at Regional Public Hospital (RSUD) Dr. Wahidin Sudiro Husodo Mojokerto city, Indonesia. A total of 117 were sampled for this study. The analysis technique is descriptive and linear regression for confirmation on a structural equation model built by the researcher. The quantitative approach was chosen to explain the influence between research variables. Data collection used a questionnaire. The results of this study found that the leadership style had led to individual motivational behaviour which ultimately had a positive impact on nurse performance. Nurse Job satisfaction affects individual motivation and nurse performance.

\section{Keywords: Leadership Style, Job Satisfaction, Motivation, Nurse Performance INTRODUCTION}

Hospital is a health service institution that organizes health services for the community and provides inpatient, outpatient, and emergency services and has medical staff and medical support that has competence by statutory provisions (RI Law No. 44, 2009). Good service is a manifestation of the success of human resources at the hospital.

Regional Public Hospital (Dr. Wahidin Sudiro Husodo) is the only government hospital in the city of Mojokerto and is a type B general hospital and is a referral center for all Public health centers, type C and type D hospitals in Mojokerto area. Thus, the role of this hospital has a big responsibility in terms of better service compared to the referring hospital. Competence Human resources and equipment are the key to the success of health care problems.

Nurses are the most human resources in health service work in hospitals. Nurses are ready to help patients at any time and most of them work extra hours beyond standard hours. Nurses work in turns and continue to provide comprehensive and professional nursing care (Department of Health, 1994).

In the current era of globalization, consumers, in this case, our patients, free to determine which service products are relevant to their desires, patients are more oriented to the level of service and affordable prices (Respati,2010). Hospital management always strives to improve employee performance including nurses. The performance of nurses is demanded to perform optimally for health services and the satisfaction of patients and their families first. To improve the performance of 
nurses hospital management must find and find out what factors influence it. In general, the factors that influence performance are internal and external. Internal factors are factors that originate in nurses, for example, intellectual ability, work discipline, work experience, job satisfaction, educational background, and motivation. External factors are factors supporting work as nurses from the environment in which they work, such as leadership style, career development, work environment, training, compensation, and management systems in the company (Hasibuan,2017).

This research, starting from the curiosity that is one of the opinions of Hasibuan (2017) about internal and external factors is a theoretical problem for hospitals in the Regional Public Hospital (Dr. Wahidin Sudiro Husodo). Researchers are interested in testing external factors namely Leadership Style and internal factors namely Job Satisfaction as exogenous factors causing Nurse Performance. Some facts show that hospital success is largely determined by the Leadership Style. Many of the hospital managements fail and are taken over by third parties due to leadership factors. Besides, job satisfaction of employees in all business and non-business organizations is a key consideration for accelerating performance.

The results of empirical studies on the influence of leadership style and job satisfaction on employee performance show different results. Profita et al. (2017) and Iqbal et al. (2015) proved that leadership style has a significant effect on employee performance. The results of Sukarja and Machasin's research (2015); Salutondok and Soegoto (2015); Sari and Hendro (2017) prove that leadership does not affect employee performance. This research gap encourages researchers to find out the right position between leadership style and individual performance, especially in hospitals.

Besides, the relationship between job satisfaction and performance is also unclear in previous empirical studies. The results of research by Chugtai and Zafar (2006), Al-Hussami (2008), Mrayyan and AlFaouri (2008), Al-Ahmadi (2009) and Khan et al. (2010) explain and prove there is a positive influence between job satisfaction and employee performance. This opinion is opposed by research conducted by Petty et al. (1984), Crossman and Zaki (2003), Muthuveloo and Rose (2005) and Chen et al. (2007) prove that there is no relationship of job satisfaction on employee performance, this happens because there is a unique phenomenon that is not informed.

Explanation of gap research on the influence of leadership and job satisfaction on individual performance, then individual motivation becomes a solution that is expected to solve theoretical problems. Therefore, a structural equation model needs to be built in this study. This study places individual motivation as an intervening variable. The individual motivation as a target to be achieved by the leadership style and job satisfaction of employees to improve the performance of nurses in the hospital.

Based on the phenomenon explained that the nurse's performance target of the General Hospital (Dr. Wahidin Sudiro Husodo) is targeting achievement for several performance indicators in the range of $90 \%$. This number is a perfect number of nurse performance. The achievement of the success of nurses' performance in the range of $80-81 \%$ each year. This figure is quite good for a hospital management measure. The implementation of human resource management in hospitals is included in the successful category. This study wants to test the truth of individual motivation as an effect that can affect nurses' performance by considering other effects namely leadership style and job satisfaction of nurses in hospitals.

\section{LITERATURE REVIEW}

\section{Nurse Performance}

Nurse performance is the activity of nurses to carry out well on an authority, duties, and responsibilities to achieve the objectives of the main tasks of the profession as a nurse and also to realize the goals and objectives of the organization. According to the Regulation of the Minister of Health of the Republic of Indonesia Number 1 of 2019 the performance evaluation of nurses consists of achieving performance targets and work behavior. Performance targets include work plans and targets to be achieved by a government employee. Work behavior includes behavior, attitudes or actions taken by government employees or not doing something that should be done by statutory provisions.

\section{Motivation}

Motivation is a psychological characteristic of humans that contributes to one's level of commitment. This includes the factors that cause, channel, and maintain human behavior in a particular direction of determination (Suarli,2009). Landy and Becker (1987) classify many modern approaches to motivational theory and practice, one of which is Achievement Theory 
(McClelland). He proposes that individual needs are obtained over time and are shaped by one's life experience. Achievement Theory describes three types of motivational needs namely Need for Achievement, Need for Affiliation and Need for Power.

\section{Leadership}

Leadership, in general, can be interpreted as art, influence, or the process of influencing others. So that requires willingness and effort toward achieving an organizational goal. So leadership is defined as someone who has the task to direct and guide subordinates and be able to get support from subordinates so that it is easy to move subordinates towards achieving an organizational goal (Mangkunegara,2006). A person's leadership style tends to be very varied and different. According to the experts, several leadership styles can be applied in organizations, one of which is the leadership style according to Robert House. This theory tries to explain how the behavior of a leader affects the satisfaction and performance of subordinates (House,1971). By House(1971) put forward four leadership styles, namely: Directive, Supportive, Participatory, and AchievementOriented.

\section{Job Satisfaction}

According to Luthans (2006), Job satisfaction is a pleasant state or positive emotion resulting from the assessment of one's work or work experience. According to Smith et al. (1969), there are several dimensions of job satisfaction that are used to express important characteristics regarding work. These indicators include Supervision, Coworkers, Promotions and Salaries / Pay.

\section{Research conceptual framework}

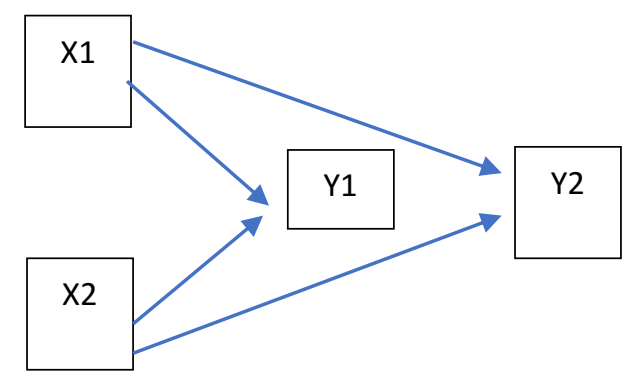

\section{Image1. Structural Equation Model}

Note: X1= Leadership style; X2= Job satisfaction; Y1= Individual Motivation; Y2= Nurse Performance RESEARCH METHODS

\section{Research Design}

The design of this study is quantitative with two research hypotheses. Description analysis is used to explain the description of each variable under study and multiple linear regression analysis is used to determine the effect between the variables tested. The questionnaire was used to collect primary data. Respondents only chose five answers according to the Likert scale on choice 1 is strongly disagree, 2 disagrees, 3 is neutral, 4 agrees and choice 5 strongly agrees.

\section{Population and Sample}

The research respondents were all civil servant nurses who worked in hospitals as many as 165 nurses. The study was conducted in the period of 6 January 2020 to 10 January 2020. The Solving formula is used to determine the sample by considering an error rate of 5\% so that a sample of 117 respondents from a population of 165 nurses is obtained. The sampling technique uses a simple random sampling technique with the consideration that each nurse has the same opportunity to answer the research questionnaire.

\section{Variables and Indicators}

Leadership style is measured by four indicators namely directive leadership style, supportive leadership style, participative leadership style, and achievement-oriented leadership style. Job satisfaction is measured by five indicators namely the job itself, salary, promotion opportunities, coworkers, and superiors. Motivation is measured by three indicators namely the need for achievement, the need for affiliation, the need for power, while the nurse's performance is measured by two indicators 
namely performance goals and work behavior. The structure of variables, indicators and the number of research instruments is presented in Table 1.

Table 1. Variables, indicators, and research instruments

\begin{tabular}{|c|c|}
\hline Variables and Indicators & Number of instruments \\
\hline Leadership style $\left(\mathrm{x}_{1}\right)$ & 5 \\
\hline Directive leadership style $\left(\mathrm{x}_{1,1}\right)$ & 5 \\
\hline Supportive leadership style $\left(\mathrm{x}_{1,2}\right)$ & 5 \\
\hline Participative leadership style $\left(\mathrm{x}_{1,3}\right)$ & 4 \\
\hline Achievement oriented leadership style $\left(\mathrm{x}_{1,4}\right)$ & 4 \\
\hline Job satisfaction $\left(\mathrm{x}_{2}\right)$ & 3 \\
\hline The job itself $\left(\mathrm{x}_{2,1}\right)$ & 4 \\
\hline Salary $\left(\mathrm{x}_{2,2}\right)$ & 3 \\
\hline Promotion opportunities $\left(\mathrm{x}_{2,3}\right)$ & 3 \\
\hline Coworkers $\left(\mathrm{x}_{2,4}\right)$ & \\
\hline Superiors $\left(\mathrm{x}_{2,5}\right)$ & 5 \\
\hline Motivation (y $)$ & 5 \\
\hline The need for achievement $\left(\mathrm{y}_{1.1}\right)$ & 5 \\
\hline The need for affiliation $\left(\mathrm{y}_{1.2}\right)$ & \\
\hline The need for power $\left(\mathrm{y}_{1.3}\right)$ & 10 \\
\hline Nurse performance $\left(\mathrm{y}_{2}\right)$ & 5 \\
\hline Performance goals $\left(\mathrm{y}_{2.1}\right)$ & 66 \\
\hline Work behavior $\left(\mathrm{y}_{2.2}\right)$ & \\
\hline \multicolumn{1}{|c|}{ Total } & \\
\hline
\end{tabular}

\section{RESEARCH RESULT}

\section{Profile of respondents}

The hospital (Dr.Wahidin Sudiro Husodo) in the city of Mojokerto is a health service institution that organizes health care activities by prioritizing treatment and recovery without neglecting the improvement of health and prevention of diseases carried out through the provision of inpatient, outpatient, emergency, medical treatment services, and medical support. The researcher measures respondents' perceptions about leadership style, job satisfaction, and motivation as intervening variables on nurse performance. The data collected were 117 questionnaire units. The profile of respondents is presented in Table 2.

Table 2. Profile of Respondents

\begin{tabular}{|l|c|c|c|}
\hline \multicolumn{1}{|c|}{ Age } & \% & Level of education & $\%$ \\
\hline 21-30 years & 18,8 & Associate Degree (D3) & 27,4 \\
\hline 31-40 years & 67,5 & Bachelor (S1) & 72,6 \\
\hline 41-50 years & 13,7 & \multirow{2}{*}{$\%$} \\
\cline { 1 - 2 } Gender & $\%$ & \\
\cline { 1 - 2 } Male & 24,8 & \\
\cline { 1 - 2 } Female & 75,2 & \\
\hline
\end{tabular}

Most respondents are women, in the age range of 31 to 40 years means that respondents are at a high level of maturity with a good level of intelligence that is mostly educated graduates.

\section{Analysis Result Description}

Analysis of data processing using the SPSS (Statistical Package for Social Science) program. There are four research variables, 12 indicators, and 66 instruments in total. The results of testing the validity and reliability for 66 items proved to be valid as evidenced by the probability that each instrument did not exceed the error rate of 5\%, meaning that the respondent 
understood the purpose of the measurements contained in the questionnaire (See Appendix). The reliability test results of the research instrument show a good level of reliability is evident from the Chronbach alpha value does not exceed the value of the $r$ table (0.181). The results of the descriptive analysis for each research variable, indicators, and 66 research instruments are presented in the appendix.

The description of respondent perception can be analyzed from the average value generated by the indicators and instrument items. The indicator that best describes leadership style variables is a supportive leadership style, especially in establishing communication with nurses and in developing a more familial atmosphere in the work environment. The indicator that best describes the variable job satisfaction, namely coworkers is reflected in good communication between coworkers. For individual motivation variables, the indicator that best describes individual motivation is the motivation for affiliated needs, reflected in the ability of nurses to establish relationships with coworkers and patients. For nurse performance variables, the main indicator that can explain nurse performance is the ability of nurses to determine work goals. This is evident in the ability of nurses to do nursing work, especially in patients and patients' families.

\section{Results of linear regression analysis}

To build a structural equation model, a regression is carried out twice. The results of the regression model equation are as follows:

The first multiple linear regression model: Y1=0,316X1+0,289X2+e1

The second multiple linear regression model: Y2=0,158X1+0,295X2+0,381Y1+e2

Note:
X1= Leadership Style;
$\mathrm{X} 2=$ Job satisfaction;
$\mathrm{Y} 1=$ Individual Motivation;
Y2= Nurse Performance

The results of the structural equation model are presented in Figure 2.

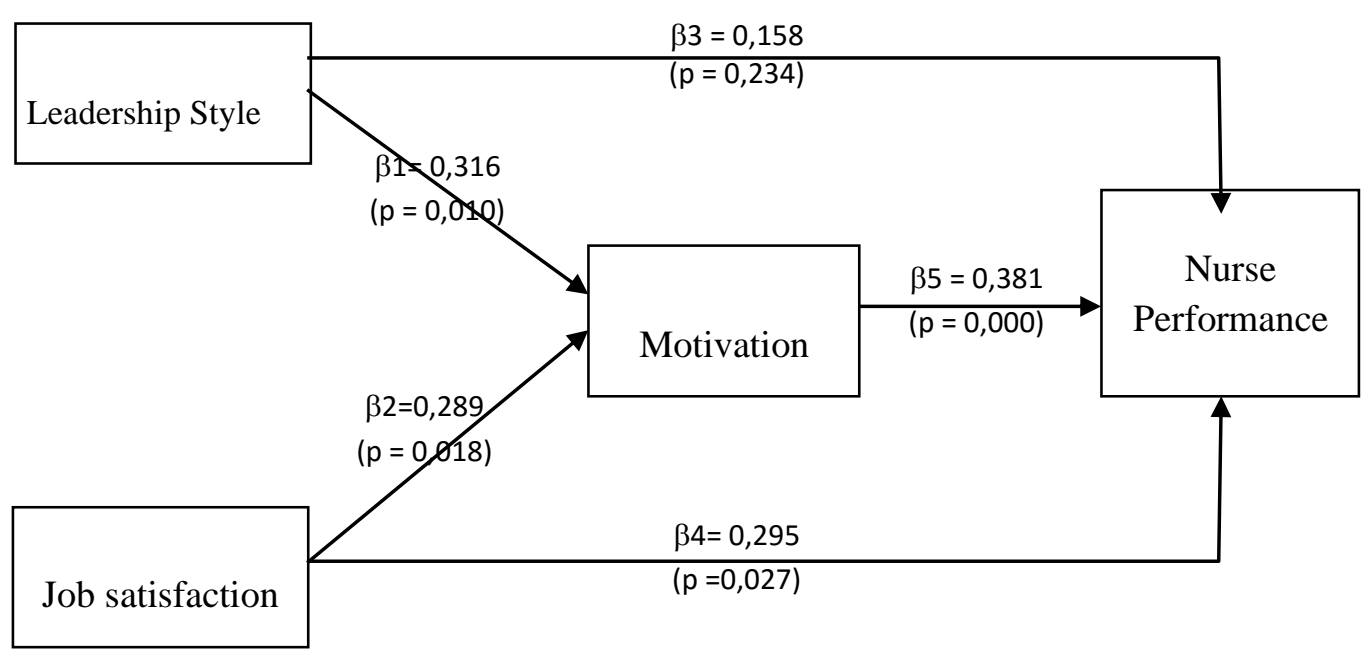

There are five regression coefficients in the structural equation model above. The leadership style regression coefficient on nurse performance showed no significant effect, while the other four regression coefficients showed a significant effect. The results of the path analysis evaluation are presented in Table 2. 
Table 2. Results of path analysis

\begin{tabular}{|c|c|c|c|c|c|c|}
\hline \multicolumn{3}{|c|}{ Variable } & \multicolumn{3}{|c|}{ Coefficients } & \multirow[t]{2}{*}{ result } \\
\hline Independent & Mediasi & Dependen & direct & indirect & Total & \\
\hline Leadership Style $\rightarrow$ & Motivation & - & $0,316^{*}$ & - & - & $\begin{array}{c}\mathrm{H} 1 \\
\text { accepted }\end{array}$ \\
\hline Job satisfaction $\rightarrow$ & Motivation & - & $0,289^{*}$ & - & - & $\begin{array}{c}\mathrm{H} 1 \\
\text { accepted }\end{array}$ \\
\hline Leadership Style $\rightarrow$ & - & Nurse Performance & 0,158 & - & - & $\begin{array}{c}\mathrm{H} 2 \\
\text { rejected }\end{array}$ \\
\hline \multirow[t]{2}{*}{ Job satisfaction } & - & Nurse Performance & $0,295^{*}$ & - & - & $\begin{array}{c}\mathrm{H} 2 \\
\text { rejected }\end{array}$ \\
\hline & Motivation $\rightarrow$ & Nurse Performance & $0,381^{*}$ & - & & $\begin{array}{c}\mathrm{H} 2 \\
\text { rejected }\end{array}$ \\
\hline Leadership Style $\rightarrow$ & Motivation $\rightarrow$ & Nurse Performance & 0,158 & $\begin{array}{c}0,316^{*} \times 0,381^{*} \\
=0,120^{*}\end{array}$ & $0,120^{*}$ & \\
\hline Job satisfaction $\rightarrow$ & Motivation $\rightarrow$ & Nurse Performance & $0,295^{*}$ & $\begin{array}{c}0,289^{*} \times 0,381^{*} \\
=0,110^{*}\end{array}$ & $0,405^{*}$ & \\
\hline
\end{tabular}

\section{Note:}

Significant level ( $p$ ) less than 5\%

Path X1 to Y2 shows no significant effect, so the coefficient value of 0.158 is considered Null

( $\beta 3=0$ or $\mathrm{H} 0$ is accepted) so this path is not calculated.

\section{DISCUSSION}

\section{Leadership Style, Job Satisfaction and Motivation}

Confirmation of the first hypothesis shows leadership style influences motivation; supportive leaders make nurses cooperative towards their responsibilities because nurses feel valued. One way for leaders to increase nurse motivation is to have regular meetings every morning. It aims to discuss the patient's condition. In other leadership styles, the head of the room often gives praise to nurses who are performing well. This compliment affects the comfort of the nurse and they feel valued. Besides, the impact on the motivation of individual nurses is to work better. The results of this study are in line with the results of research Rizqiyah et al. (2013) which proves that there is an influence of supportive leadership style on employee work motivation.

The first hypothesis confirmation proposes that job satisfaction influences the motivation of individual nurses. The results of this study indicate that job satisfaction with coworkers has a positive effect on nurses' motivation to make interactions with colleagues and patients in the hospital environment where they work. The findings of this study are in line with Afifah's research (2017) which proves that the welfare of the people is significantly positive and significantly motivates the motivation of the relative welfare.

\section{Leadership Style, Job Satisfaction, Individual Motivation, and Nurse Performance}

The test results show that the leadership style does not affect nurse performance. This finding shows the phenomenon in the hospital that the directive, supportive, participatory and achievement orientation leadership style that was carried out by the leadership in the hospital proved to not affect nurses' performance. This means that nurses directly do not need a leadership style. Nurses need stimulants, namely individual motivation to interact with colleagues rather than leadership style. Hospital management systems have succeeded in creating job satisfaction with nurses' work, salaries, and promotions so that they do not directly need leadership models/styles. 
On the other hand, this study is interesting that the application of leadership styles that occur in hospitals has proven to lead to nurses' motivation to interact with colleagues and patients. This interaction has a positive impact on the performance of nurses to complete the goals of nursing work. The relationship between leadership style and nurse performance is in line with research conducted by Hidayat (2011) research which says leadership style does not have a significant effect on performance.

The relationship between job satisfaction and nurse performance proves that there is an influence. This shows that organizations with more satisfied nurses have a higher level of performance than less satisfied nurses. The results of this study support previous research conducted by Al-Ahmadi (2009); Al-Hussami, (2008); Mrayyan \& AlFaouri (2008); there is a positive relationship between job satisfaction and employee performance. The interesting thing is the nurse's job satisfaction for coworkers has an impact on individual motivation to establish good relationships with colleagues. This activity is proven to have an impact on the performance of nurses to complete their work goals.

\section{CONCLUSIONS AND RECOMMENDATIONS}

The results of the study prove that the leadership style in the hospital under study leads to individual motivation and ultimately has an impact on nurse performance. Leadership style directly has no impact on nurse performance. Nurse job satisfaction has a direct impact on nurse performance. Job satisfaction can grow individual motivation and ultimately have an impact on nurse performance. The management system in the hospital is suspected to have been able to create nurse job satisfaction. For this reason, researchers are advised to conduct an in-depth study of management systems such as quality control groups or the implementation of total quality management, which is primarily a system of continuous improvement and the commitment of leaders. So the following modeling that researchers suggest is presented in Figure 3.

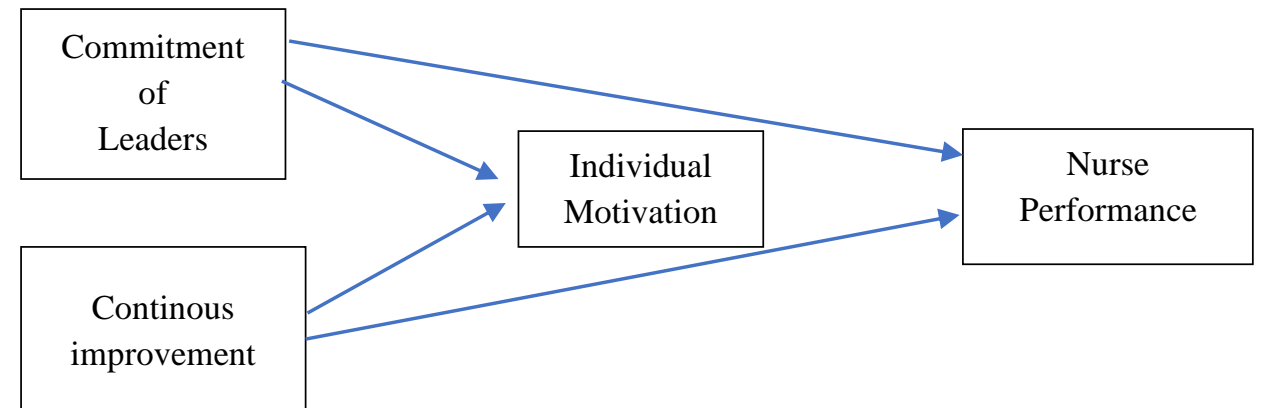

Figure 3

Structural Equation Model Proposal REFERENCES

Afifah, Thara and Al Musadieq, Mochammad, (2017). " Pengaruh Kepuasan Kerja Terhadap Motivasi Kerja dan Dampaknya Terhadap Kinerja (Studi pada Karyawan PT Pertamina Geothermal Energy Kantor Pusat Jakarta)". Faculty of Administrative Sciences, Brawijaya University Malang. Journal of Business Administration (JAB). Vol. 47 June 1, 2017.

Al-Ahmadi, H., (2009). "Factors Affecting Performance of Nurses Hospital in Riyadh Region, Saudi Arabia". International Journal of Health Care Quality Assurance. Vol. 22, No. 1, pp. 40-54.

Al-Hussami, M., (2008). "A Study of Nurses' Job Satisfaction: The Relationship to Organizational Commitment, Perceived Organizational Support, Transactional Leadership, Transformational Leadership, and Level of Education". European Journal of Scientific Research.Vol. 22 No.2, pp.286-295.

Chen, S.J., P.F. Lin, C.M. Lu, and C.W. Tsao, (2007). "The Moderation Effect of HR Strength on the Relationship Between Employee Commitment and Job Performance". Social Behavior and Personality, Vol. 35, No.8, pg. 1121 - 1138.

Chugtai, A.A, and S. Zafar, (2006). "Antecedents and Consequences of Organizational Commitment among Pakistani University Teachers". Journal of Applied HRM Research, Vol. 11 No. 1, pp. 39-64. 
Crossman, A. and B. Abou-Zaki, (2003). "Job Satisfaction and Employee Performance of Lebanese Banking Staff". Journal of Managerial Psychology. Vol. 18, No.4, pp. 368-376.

Ministry of Health of the Republic of Indonesia. (1994). Pedoman Uraian Tugas Tenaga Kesehatan di Rumah Sakit. Jakarta.

Do Rêgo, E.B., Supartha, W.G., and Yasa, N.N.K., (2017). "Pengaruh Kepemimpinan Terhadap Motivasi dan Kinerja Karyawan pada Direktorat Jendral Administrasi dan Keuangan, Kementerian Estatal Timor Leste". E-Journal of Economics and Business, Udayana University. Vol 6 No.11, pp 3731-3764.

Hasibuan, Malayu S.P., (2017). " Manajemen Sumber Daya Manusia". Revised Edition. Earth Literacy. Jakarta.

House, Robert, J. (1971). "A path-goal theory of leader effectiveness". Administrative Science Quarterly, Vol.16: $321-339$.

Iqbal, N. Anwar, S., and Haider, N., (2015). "Effect of Leadership Style on Employee Performance", Arabian Journal of Business and Management Review, Vol. 5 No.2.

Khan, M.R., Ziauddin, F.A. Jam, and M.I. Ramay, (2010). "The Impacts of Organizational Commitment on Employee Job Performance", European Journal of Social Sciences, Vol.15, No. 3, pp. 292-298.

Landy, F. J., and Becker, W. S. (1987). " Motivation theory reconsidered”. Research in Organizational Behavior, 9, 1-38

Luthans, Fred. (2006). "Perilaku Organisasi". 10th Indonesian Edition. Yogyakarta: PT. Andi Offset.

Mangkunegara, Anwar Prabu, 2006. "Perencanaan dan Pengembangan Manajemen Sumber Daya Manusia". Bandung: PT Refika Aditama.

Mrayyan, M.T., and I. Al-Faouri. (2008). "Career Commitment and Job Performance of Jordanian Nurses". Nursing Forum. Vol. 43 No. 1, pp 24-37.

Muthuveloo, R. and R.C. Rose, (2005). "Antecedents and Outcomes of Organizational Commitment among Malaysian Engineers", American Journal of Applied Sciences, Vol.2 No.6, pp.1095-1100.

Regulation of the Minister of Health of the Republic of Indonesia Number 01 of 2019 concerning Guidelines for Appraisal of Employee Performance in the Ministry of Health.

Petty, M.M., G.W. McGee, and J.W. Cavender, (1984). "A Meta-Analysis of the Relationships Between Individual Job Satisfaction and Individual Performance". The Academy of Management Review. Vol. 9, No. 4, pp 712-721.

Profita, D., and Surachman, Andarwati, (2017). "Pengaruh kepemimpinan, budaya organisasi, motivasi terhadap kepuasan kerja dan kinerja karyawan pada dinas pemerintahanan desa kabupaten lumajang (pemdes)". Journal of Business and Management, Vol. 4 No.2, pp. 142-152.

Respati, Harianto. (2010). "Total Quality Manajemen dan Daya Saing Perusahaan sebagai Antesenden Kepuasan Pelanggan Menghadapi CAFTA 2010”. Iqtishoduna, Journal of Islamic Economics and Business. Vol.6.No.1. pp.1-14

Rizqiyah, I.A., Rahardjo, Kusdi., And Utami, H.N.,(2013). "Pengaruh Gaya Kepemimpinan Terhadap Motivasi Kerja Karyawan (Studi Pada Karyawan PT. Temprina Media Grafika Surabaya)". Universitas Brawijaya Business Administration Journal. Vol. 4 No. 1

Salutondok, Y., and Soegoto, U.S., (2015). "Pengaruh kepemimpinan, motivasi, kondisi kerja dan disiplin terhadap kinerja pegawai di kantor sekretariat DPRD kota Sorong”. EMBA Journal. Vol.3 No.3, pp. 849-862.

Sari, S., and Hendro, O., (2017). "Pengaruh kreativitas, komunikasi, dan kepemimpinan guru terhadap prestasi belajar siswa pada smp negeri di kecamatan ilir timur palembang”. Global Ecoment Journal. Vol. 2 No. 1

Smith, P.C., Kendall, L., and Hulin, C.L., (1969). "The Measurement of Satisfaction in Work and Retirement". Chicago: Randy McNally.

Suarli, S and Bahtiar Y., (2009). "Manajemen Keperawatan dengan Pendekatan Praktis", Erlangga. Jakarta

Sukarja, R., Machasin, (2015). "Pengaruh Kepemimpinan Dan Komunikasi Terhadap Kepuasan Kerja Dan Kinerja Pegawai Dinas Pendidikan Provinsi Riau". Journal of Boxing Business Management. Vol. 7, No. 2 pp 270-284.

Republic of Indonesia Law No. 44 of 2009 concerning Hospitals. Jakarta. 
The test results and the descriptive analysis instruments

\begin{tabular}{|c|c|c|c|c|c|}
\hline Variables and Indicators & $\begin{array}{l}\text { Instrument's } \\
\text { code }\end{array}$ & $\begin{array}{l}\text { Correlation } \\
\text { coefficient }\end{array}$ & $\begin{array}{c}\text { The } \\
\text { reliability } \\
\text { coefficient }\end{array}$ & \multicolumn{2}{|c|}{ mean } \\
\hline Leadership style (X1) & & & 0,9579 & \multicolumn{2}{|c|}{4.03} \\
\hline \multirow[t]{5}{*}{ Directive Leadership Style (X1.1) } & $\mathrm{X} 1.1 .1$ & .894 & & 4.06 & \multirow[t]{5}{*}{4.08} \\
\hline & $\mathrm{X} 1.1 .2$ & 0,893 & & 4.08 & \\
\hline & $\mathrm{X} 1.1 .3$ & .894 & & 4.03 & \\
\hline & $\mathrm{X} 1.1 .4$ & 0.865 & & 4.09 & \\
\hline & $\mathrm{X} 1.1 .5$ & 0,862 & & 4.15 & \\
\hline \multirow[t]{5}{*}{ Supportive Leadership Style (X1.2) } & $\mathrm{X} 1.2 .1$ & .921 & & 4.17 & \multirow[t]{5}{*}{4.14} \\
\hline & $\mathrm{X} 1.2 .2$ & 0.907 & & 4.16 & \\
\hline & $\mathrm{X} 1.2 .3$ & 0.847 & & 4.16 & \\
\hline & $\mathrm{X} 1.2 .4$ & .902 & & 4,05 & \\
\hline & $\mathrm{X} 1.2 .5$ & 0.802 & & 4.17 & \\
\hline \multirow[t]{5}{*}{ Participative Leadership Style (X1.3) } & $\mathrm{X} 1.3 .1$ & .852 & & 4.00 & \multirow[t]{5}{*}{4.02} \\
\hline & $\mathrm{X} 1.3 .2$ & 0.884 & & 3.92 & \\
\hline & $\mathrm{X} 1.3 .3$ & 0,906 & & 4.10 & \\
\hline & $\mathrm{X} 1.3 .4$ & .902 & & 4.00 & \\
\hline & $\mathrm{X} 1.3 .5$ & 0,844 & & 4.07 & \\
\hline \multirow[t]{4}{*}{$\begin{array}{l}\text { Achievement Orientated Leadership Style } \\
(\mathrm{X} 1.4)\end{array}$} & $\mathrm{X} 1.4 .1$ & 0.799 & & 3.62 & \multirow[t]{4}{*}{3.89} \\
\hline & $\mathrm{X} 1.4 .2$ & 0.901 & & 4.00 & \\
\hline & $\mathrm{X} 1.4 .3$ & .914 & & 3.92 & \\
\hline & $\mathrm{X} 1.4 .4$ & 0.895 & & 4.01 & \\
\hline Job Satisfaction (X2) & & & .9042 & \multicolumn{2}{|c|}{3.93} \\
\hline \multirow[t]{4}{*}{ The job Itself (X2.1) } & $\mathrm{X} 2.1 .1$ & .774 & & 4.20 & \multirow[t]{4}{*}{4.06} \\
\hline & $\mathrm{X} 2.1 .2$ & 0.915 & & 4.10 & \\
\hline & $\mathrm{X} 2.1 .3$ & 0.872 & & 4.11 & \\
\hline & $\mathrm{X} 2.1 .4$ & 0.805 & & 3.84 & \\
\hline \multirow[t]{3}{*}{ Salary (X2.2) } & $\mathrm{X} 2.2 .1$ & 0.827 & & 3.67 & \multirow{3}{*}{3.58} \\
\hline & $\mathrm{X} 2.2 .2$ & 0.911 & & 3.58 & \\
\hline & $\mathrm{X} 2.2 .3$ & 0,877 & & 3.47 & \\
\hline \multirow[t]{4}{*}{ Promotion opportunities (X2.3) } & $\mathrm{X} 2.3 .1$ & .434 & & 3.92 & \multirow{4}{*}{3.69} \\
\hline & $\mathrm{X} 2.3 .2$ & 0.817 & & 3.61 & \\
\hline & $\mathrm{X} 2.3 .3$ & 0.876 & & 3.66 & \\
\hline & $\mathrm{X} 2.3 .4$ & .871 & & 3.56 & \\
\hline \multirow[t]{3}{*}{ Coworkers (X2.4) } & $\mathrm{X} 2.4 .1$ & 0.905 & & 4.21 & \multirow{3}{*}{4.24} \\
\hline & $\mathrm{X} 2.4 .2$ & 0.941 & & 4.28 & \\
\hline & $\mathrm{X} 2.4 .3$ & 0.905 & & 4.23 & \\
\hline \multirow[t]{3}{*}{ Superiors (X2.5) } & $\mathrm{X} 2.5 .1$ & 0.867 & & 4.00 & \multirow{3}{*}{4.08} \\
\hline & $\mathrm{X} 2.5 .2$ & 0.931 & & 4.11 & \\
\hline & $\mathrm{X} 2.5 .3$ & .923 & & 4.13 & \\
\hline Motivation (Y1) & & & 0.8730 & \multicolumn{2}{|c|}{3.73} \\
\hline The need for achievement (Y 1.1) & Y1.1.1 & 0,729 & & 4.24 & \\
\hline & $\mathrm{Y} 1.1 .2$ & .838 & & 3.71 & \\
\hline & Y1.1.3 & 0.785 & & 4.16 & 3.98 \\
\hline & Y1.1.4 & 0,862 & & 4.04 & \\
\hline & Y1.1.5 & 0,548 & & 3.76 & \\
\hline The need for affiliation (Y1.2) & Y1.2.1 & 0.717 & & 4.12 & \\
\hline & $\mathrm{Y} 1.2 .2$ & .673 & & 3.64 & 4.00 \\
\hline & $\mathrm{Y} 1.2 .3$ & .788 & & 4.11 & \\
\hline
\end{tabular}




\begin{tabular}{|c|c|c|c|c|c|}
\hline & Y1.2.4 & 0.776 & & 4.01 & \multirow{7}{*}{3.22} \\
\hline & Y1.2.5 & .757 & & 4.09 & \\
\hline \multirow[t]{5}{*}{ The need for power (Y1.3) } & Y1.3.1 & .808 & & 3.02 & \\
\hline & Y1.3.2 & 0.821 & & 3.17 & \\
\hline & Y1.3.3 & .834 & & 3.26 & \\
\hline & Y1.3.4 & .864 & & 3.09 & \\
\hline & Y1.3.5 & 0,703 & & 3.53 & \\
\hline Nurse Performance (Y2) & & & .6259 & \multicolumn{2}{|c|}{4.30} \\
\hline \multirow[t]{10}{*}{ Performance goals (Y2.1) } & Y2.1.1 & .777 & & 4.64 & \multirow{10}{*}{4.24} \\
\hline & Y2.1.2 & 0.345 & & 4.41 & \\
\hline & Y2.1.3 & .563 & & 4.23 & \\
\hline & Y2.1.4 & 0.432 & & 4.24 & \\
\hline & Y2.1.5 & 0,478 & & 4.29 & \\
\hline & Y2.1.6 & 0.481 & & 4.13 & \\
\hline & Y2.1.7 & 0.513 & & 4,05 & \\
\hline & Y2.1.8 & .443 & & 4.39 & \\
\hline & Y2.1.9 & 0,459 & & 4.02 & \\
\hline & Y2.1.10 & .419 & & 3.97 & \\
\hline \multirow[t]{5}{*}{ Work Behavior (Y2.2) } & Y2.2.1 & 0.847 & & 4.47 & \multirow{5}{*}{4.36} \\
\hline & Y2.2.2 & .811 & & 4.44 & \\
\hline & Y2.2.3 & 0.722 & & 4.22 & \\
\hline & Y2.2.4 & .793 & & 4.29 & \\
\hline & Y2.2.5 & .786 & & 4.41 & \\
\hline
\end{tabular}

Note:

\begin{tabular}{|c|c|c|}
\hline \multicolumn{3}{|l|}{ Leadership style (X1) } \\
\hline \multirow{5}{*}{ Directive Leadership Style (X1.1) } & $\mathrm{X} 1.1 .1$ & My supervisor gives direct work directives \\
\hline & $\mathrm{X} 1.1 .2$ & My supervisor explained what had to be \\
\hline & $\mathrm{X} 1.1 .3$ & $\begin{array}{l}\text { My supervisor gave instructions to the } \\
\text { employees }\end{array}$ \\
\hline & $\mathrm{X} 1.1 .4$ & $\begin{array}{l}\text { My supervisor is being firm in making } \\
\text { decisions }\end{array}$ \\
\hline & $\mathrm{X} 1.1 .5$ & $\begin{array}{l}\text { My supervisor involves the nurse in asking for } \\
\text { advice/opinions }\end{array}$ \\
\hline \multirow[t]{5}{*}{ Supportive Leadership Style (X1.2) } & $\mathrm{X} 1.2 .1$ & $\begin{array}{l}\text { My supervisor established communication with } \\
\text { the nurses }\end{array}$ \\
\hline & $\mathrm{X} 1.2 .2$ & $\begin{array}{l}\text { My supervisor maintains a friendly working } \\
\text { relationship with nurses }\end{array}$ \\
\hline & $\mathrm{X} 1.2 .3$ & $\begin{array}{l}\text { The supervisor provides work solutions when } \\
\text { there are questions from nurses }\end{array}$ \\
\hline & $\mathrm{X} 1.2 .4$ & $\begin{array}{l}\text { My supervisor creates a pleasant working } \\
\text { atmosphere }\end{array}$ \\
\hline & $\mathrm{X} 1.2 .5$ & $\begin{array}{l}\text { Supervisor develop a more familial atmosphere } \\
\text { in the work environment }\end{array}$ \\
\hline \multirow[t]{4}{*}{ Participatory Leadership Style (X1.3) } & $\mathrm{X} 1.3 .1$ & $\begin{array}{l}\text { Supervisor consider information from nurses in } \\
\text { decision making }\end{array}$ \\
\hline & $\mathrm{X} 1.3 .2$ & $\begin{array}{l}\text { My supervisor involves subordinates in making } \\
\text { a decision }\end{array}$ \\
\hline & $\mathrm{X} 1.3 .3$ & $\begin{array}{l}\text { The supervisor is responsible for decision } \\
\text { making }\end{array}$ \\
\hline & $\mathrm{X} 1.3 .4$ & $\begin{array}{l}\text { My supervisor increased the nurse's ability to } \\
\text { complete work assignments }\end{array}$ \\
\hline
\end{tabular}




\begin{tabular}{|c|c|c|}
\hline & $\mathrm{X} 1.3 .5$ & $\begin{array}{l}\text { My supervisor provides an opportunity for } \\
\text { nurses to complete work assignments } \\
\text { independently }\end{array}$ \\
\hline \multirow[t]{4}{*}{$\begin{array}{l}\text { Achievement Orientation Leadership Style } \\
\text { (X1.4) }\end{array}$} & $\mathrm{X} 1.4 .1$ & $\begin{array}{l}\text { My supervisor gave a challenging job to the } \\
\text { nurse }\end{array}$ \\
\hline & $\mathrm{X} 1.4 .2$ & $\begin{array}{l}\text { The supervisor advises on performance to } \\
\text { nurses }\end{array}$ \\
\hline & $\mathrm{X} 1.4 .3$ & $\begin{array}{l}\text { The supervisor gives direction on the } \\
\text { achievement of minimum performance } \\
\text { standards }\end{array}$ \\
\hline & $\mathrm{X} 1.4 .4$ & Supervisor motivate nurses to work optimally \\
\hline \multicolumn{3}{|l|}{ Job Satisfaction (X2) } \\
\hline \multirow[t]{4}{*}{ Work Itself (X2.1) } & $\mathrm{X} 2.1 .1$ & Work experience adds better work techniques. \\
\hline & $\mathrm{X} 2.1 .2$ & There is an opportunity to be creative at work \\
\hline & $\mathrm{X} 2.1 .3$ & $\begin{array}{l}\text { I was given responsibilities that were within my } \\
\text { capabilities. }\end{array}$ \\
\hline & $\mathrm{X} 2.1 .4$ & I feel there is career development in this work. \\
\hline \multirow[t]{3}{*}{ Salary (X2.2) } & $\mathrm{X} 2.2 .1$ & $\begin{array}{l}\text { Basic needs are fulfilled from my monthly } \\
\text { salary }\end{array}$ \\
\hline & $\mathrm{X} 2.2 .2$ & $\begin{array}{l}\text { The reward system established by the hospital } \\
\text { is my sacrifice. }\end{array}$ \\
\hline & $\mathrm{X} 2.2 .3$ & $\begin{array}{l}\text { I get a plaque award and compensation for } \\
\text { achievement. }\end{array}$ \\
\hline \multirow[t]{4}{*}{ Promotion opportunities (X2.3) } & $\mathrm{X} 2.3 .1$ & $\begin{array}{l}\text { The opportunity to take part in training made } \\
\text { my ability to work increase. }\end{array}$ \\
\hline & $\mathrm{X} 2.3 .2$ & $\begin{array}{l}\text { Hospitals provide opportunities for higher } \\
\text { positions }\end{array}$ \\
\hline & $\mathrm{X} 2.3 .3$ & $\begin{array}{l}\text { The promotion system encouraged me to work } \\
\text { more diligently. }\end{array}$ \\
\hline & $\mathrm{X} 2.3 .4$ & $\begin{array}{l}\text { I tried my best to complete my hospital duties } \\
\text { to get a promotion }\end{array}$ \\
\hline \multirow[t]{3}{*}{ Coworkers (X2.4) } & $\mathrm{X} 2.4 .1$ & Coworkers help each other when working \\
\hline & $\mathrm{X} 2.4 .2$ & $\begin{array}{l}\text { There is good communication between } \\
\text { colleagues }\end{array}$ \\
\hline & $\mathrm{X} 2.4 .3$ & $\begin{array}{l}\text { My coworkers provide support and work- } \\
\text { related advice. }\end{array}$ \\
\hline \multirow[t]{3}{*}{ Superior (X2.5) } & $\mathrm{X} 2.5 .1$ & My supervisor oversees my work. \\
\hline & $\mathrm{X} 2.5 .2$ & $\begin{array}{l}\text { My supervisor can give advice and help when I } \\
\text { have difficulties. }\end{array}$ \\
\hline & $\mathrm{X} 2.5 .3$ & $\begin{array}{l}\text { My supervisor can communicate well in the } \\
\text { context of explaining work }\end{array}$ \\
\hline \multicolumn{3}{|l|}{ Motivation (Y1) } \\
\hline \multirow[t]{5}{*}{ Need for achievement (Y 1.1) } & Y1.1.1 & I try earnestly to achieve the targets given. \\
\hline & $\mathrm{Y} 1.1 .2$ & I enjoy challenging targets \\
\hline & Y1.1.3 & $\begin{array}{l}\text { I want to add insight into the effort to achieve } \\
\text { the target }\end{array}$ \\
\hline & Y1.1.4 & I like to set goals and achieve realistic goals. \\
\hline & Y1.1.5 & $\begin{array}{l}\text { The hospital appreciated high work } \\
\text { performance. }\end{array}$ \\
\hline \multirow[t]{3}{*}{ Needs affiliation (Y1.2) } & Y1.2.1 & $\begin{array}{l}\text { I interact with people around about various } \\
\text { things }\end{array}$ \\
\hline & Y1.2.2 & I am liked by others \\
\hline & Y1.2.3 & $\begin{array}{l}\text { I build close relationships with colleagues and } \\
\text { patients. }\end{array}$ \\
\hline
\end{tabular}




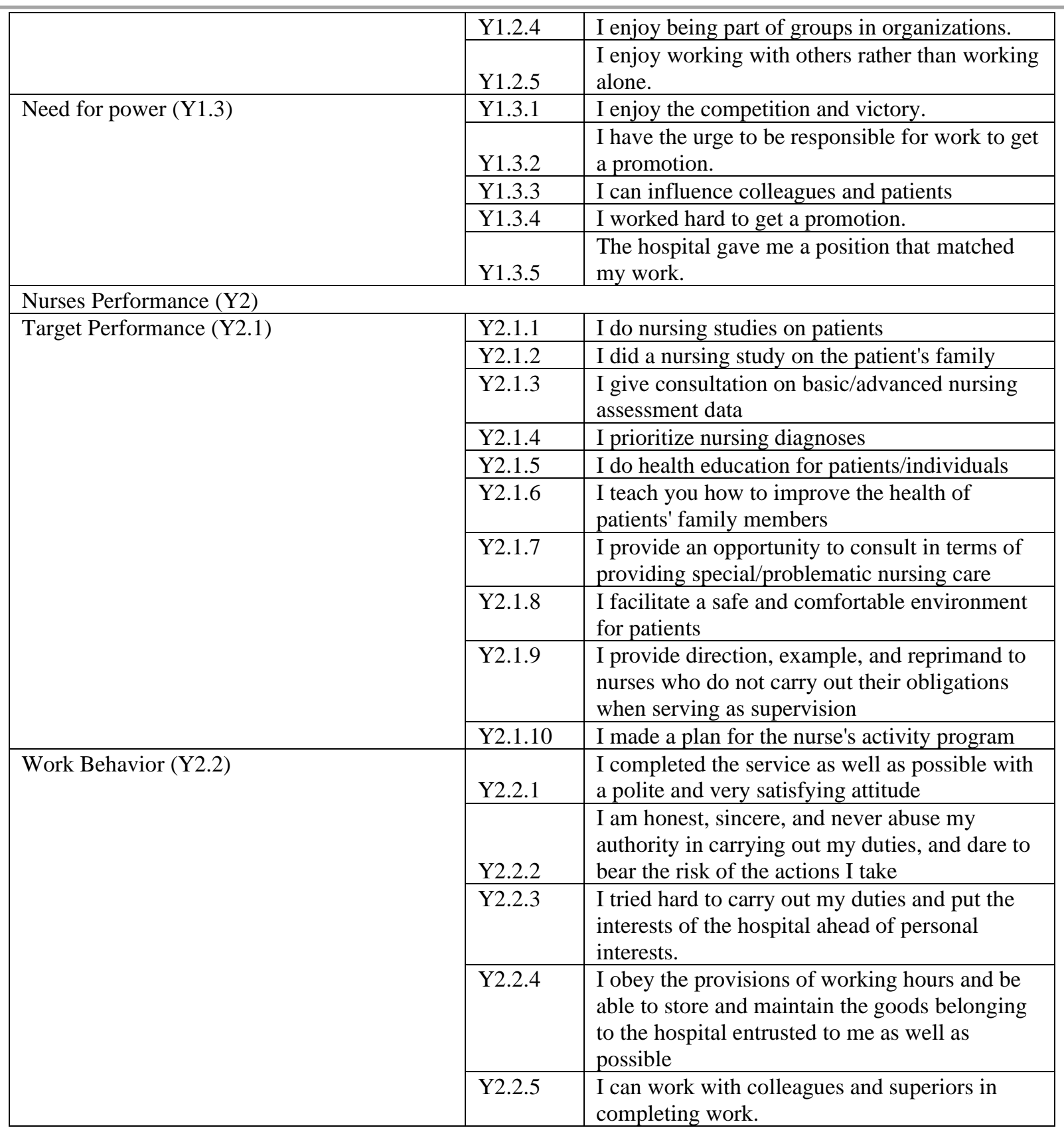

